\title{
PLANTLET REGENERATION FROM SEEDLING EXPLANTS OF SWEET GOURD
}

\author{
J. Akter, M. S. Haque and M. A. Karim ${ }^{1}$ \\ Department of Biotechnology, Bangladesh Agricultural University \\ Mymensingh-2202, Bangladesh
}

\begin{abstract}
To regenerate plantlets both directly and indirectly, different explants (cotyledon, hypocotyl, root tip and shoot tip) of sweet gourd (Cucurbita moschata) were cultured on medium supplemented with different concentrations and combinations of NAA $(0.0,0.2,0.5$ and $1.0 \mathrm{mg} / \mathrm{L})$ and $\operatorname{BAP}(0.0,0.5,2.0$ and $5.0 \mathrm{mg} / \mathrm{L})$. Cotyledon explants performed best in callus induction. The combination of $5 \mathrm{mg} / \mathrm{L} \mathrm{BAP}$ and $0.2 \mathrm{mg} / \mathrm{L}$ NAA produced the highest callus frequency in cotyledon $(90.0 \%)$. The calli derived from cotyledon, hypocotyl and root tip were cultured in MS medium supplemented with different concentrations of kinetin, BAP and/or NAA for shoot induction. Regeneration via callus was achieved only from cotyledon calli at a frequency of $65.0 \%$ on $2 \mathrm{mg} / \mathrm{L} \mathrm{BAP}$ and $0.2 \mathrm{mg} / \mathrm{L}$ NAA. Shoot tips cultured for direct regeneration, in the same media containing $1 \mathrm{mg} / \mathrm{L}$ BAP or $1 \mathrm{mg} / \mathrm{L} \mathrm{BAP}+0.2 \mathrm{mg} / \mathrm{L}$ NAA resulted in $100.0 \%$ shoot differentiation. The regenerated shoots rooted on MS medium with or without $0.1 \mathrm{mg} / \mathrm{L}$ NAA $(100 \%)$.
\end{abstract}

Key Words : Callus, Plantlet, Regeneration, Seedling explants, Sweet gourd

\section{INTRODUCTION}

Sweet gourd (Cucurbita moschata Duchex Poir) is an important vegetable in Bangladesh. It is a seed propagated, day-neutral, annual, monoecious vine crop. It is grown in all districts of Bangladesh round the year. However, its production is concentrated during summer season. It is a good source of carbohydrates, soluble fibre and $\beta$-carotinoid. It also contains protein, oils and vitamin E in the seeds. Among all the cucurbits, sweet gourd is the richest source of carotene. Immature fleshy green leaves, tender shoots and male flowers are also used as vegetables, and contain appreciable amount of vitamins and minerals (Robinson and Walters, 1997). This crop is, therefore, thought to have potentiality to solve malnutrition problem of Bangladesh to certain extent particularly of the vulnerable groups in respect of vitamin A requirement.

Improvement of sweet gourd and development of variety are obviously necessary. Tissue culture could be potentially applied for the purpose. Unfortunately there have been only few attempts to regenerate sweet gourd via tissue culture (Zhao, 1999; Hegazi, 1999). The

${ }^{1}$ Department of Crop Botany, Bangladesh Agricultural University, Mymensingh-2202, Bangladesh 
present study was therefore, undertaken to find out the suitable explant and medium for rapid in vitro regeneration protocol of sweet gourd for possible utilization in genetic improvement in future studies.

\section{MATERIALS AND METHODS}

Healthy seeds were collected and washed in tap water. The seeds were then sterilized with $70 \%$ ethanol for one minute and then rinsed with sterile distilled water. Afterwards, the seeds were soaked in $0.1 \% \mathrm{HgCl}_{2}$ plus two drops of a liquid detergent (Tween-20) solution and then agitated gently for 15-20 minutes, followed by 4 rinses in sterilized distilled water. The seeds were aseptically germinated on half MS medium. Cotyledons, hypocotyls and root tips were excised aseptically from 10-12 days old seedlings and cultured on MS medium containing different concentrations and combinations of BAP $(0.0,0.5,2.0$ and $5.0 \mathrm{mg} / \mathrm{L})$ and NAA $(0.0,0.2,0.5$ and $1.0 \mathrm{mg} / \mathrm{L})$. Subcultures were carried out at 21 days interval and finally the calli were transferred to MS medium with different concentrations of cytokinins (BAP and Kinetin) and auxin (NAA) singly or in combination. Shoot tips were also cultured on the same media. The regenerated shoots were rooted in hormone free $1 / 2$ MS media, hormone free MS media and MS media with different concentrations of NAA $(0.1,0.2,0.3,0.4$ and $0.5 \mathrm{mg} / \mathrm{L})$.

The $\mathrm{pH}$ of the medium was adjusted to 5.8 prior to the addition of agar @ 8.0g/1 and the medium was autoclaved at $121^{\circ} \mathrm{C}$ for 30 minutes. Twenty explants were cultured per treatment and each treatment was replicated 4 times. All cultures were maintained at 26 $\pm 1^{\circ} \mathrm{C}$ under white fluorescent tubes with a $16 \mathrm{~h}$ photoperiod.

\section{RESULTS AND DISCUSSION}

The results revealed that a high variation in callus induction ability was demonstrated by the explants and treatments under present study. Among the various explants, cotyledon performed best for callus induction. Cotyledon explants had the highest frequency $(53.44 \%)$ of callus and required minimum number of days (12.81) (Table 1).

NAA and BAP combinations had significant effect on callus induction. The minimum number of days (18.0) required for callusing and the highest percentage $(83.33 \%)$ were observed at $5 \mathrm{mg} / \mathrm{L}$ BAP combined with $0.2 \mathrm{mg} / \mathrm{L}$ NAA. The callus weight $(1.48 \mathrm{~g})$ was also highest at this combination (Table 1). The combined effects of growth regulators and explants revealed that, cotyledon explants showed the best performance in percentage of callus induction (90.0\%) at $5 \mathrm{mg} / \mathrm{L} \mathrm{BAP}$ and $0.2 \mathrm{mg} / \mathrm{L}$ NAA (Fig. 1A). The combination of $4.44 \mu \mathrm{M} \mathrm{BA}+2.69 \mu \mathrm{M}$ NAA was reported to be the most suitable for callus induction from cotyledon explants of cucumber (Selvaraj et al., 2007). Urbanek et al. (2005) reported callus formation from cotyledon of styrian pumpkin with $26.85 \mu \mathrm{M}$ NAA and $13.32 \mu \mathrm{M}$ BA. The results of the present study also showed that a combination of auxin and cytokinin effectively induced callus from cotyledon explants of sweet gourd.

Different concentrations of BAP or kinetin alone and BAP in combination with NAA were used to investigate the shoot induction capability of calli or different explants. 
Among the explants used, shoot tip explants exhibited best performance (76.56\%) followed by cotyledon (17.19\%). It was also evident that shoot regeneration was not achieved from hypocotyl and root tip derived calli. The highest percentage $(80.0 \%)$ of shoots regenerated at the combination of $2 \mathrm{mg} / \mathrm{L} \mathrm{BAP}$ and $0.2 \mathrm{mg} / \mathrm{L} \mathrm{NAA}$ (Fig. 1B). Considering the combined effect of explants and kinetin, BAP and/or NAA, 100.0\% shoot was regenerated at $1 \mathrm{mg} / \mathrm{L} \mathrm{BAP}$ as well as $1 \mathrm{mg} / \mathrm{L} \mathrm{BAP}$ and $0.2 \mathrm{mg} / \mathrm{L} \mathrm{NAA}$ from shoot tip explants via direct regeneration (Table 2). Similar result was also reported by Awal et al. (2005). The least number of days (8.25) and highest number of shoots per explants (13.25) were evident at BAP $1 \mathrm{mg} / \mathrm{L}$. Shoot tip explants also had the tallest shoot $(4.45 \mathrm{~cm})$ with $1 \mathrm{mg} / \mathrm{L}$ BAP and $0.2 \mathrm{mg} / \mathrm{L} \mathrm{NAA}$. The present finding agrees well with that of Vasudevan et al. (2001). The regeneration of shoots from cotyledon derived callus was not so satisfactory. The percentage of shoot regenerated from cotyledon derived callus was 65.0 and it required 50.50 days to initiate shoot (Table 2).

Table 1. Main effect of hormone concentrations on callus induction

\begin{tabular}{|c|c|c|c|c|}
\hline $\begin{array}{l}\text { Hormone concentration } \\
\text { (mg/L) } \\
\text { NAA + BAP }\end{array}$ & $\begin{array}{l}\% \text { Callus } \\
\text { induction }\end{array}$ & $\begin{array}{l}\text { Days required } \\
\text { for callus } \\
\text { induction }\end{array}$ & $\begin{array}{l}\text { Weight of callus } \\
(\mathrm{g})\end{array}$ & Nature of callus \\
\hline $0.0+0.0\left(\mathrm{~T}_{1}\right)$ & $0.00 \mathrm{j}$ & $0.00 \mathrm{f}$ & $0.00 \mathrm{~h}$ & - \\
\hline $0.0+0.5\left(\mathrm{~T}_{2}\right)$ & $33.75 \mathrm{i}$ & $22.50 \mathrm{a}$ & $0.37 \mathrm{~g}$ & Friable \\
\hline $0.0+2\left(\mathrm{~T}_{3}\right)$ & $37.50 \mathrm{~h}$ & $22.83 \mathrm{a}$ & $0.34 \mathrm{~g}$ & Friable \\
\hline $0.0+5\left(\mathrm{~T}_{4}\right)$ & $39.17 \mathrm{~h}$ & $23.17 \mathrm{a}$ & $0.34 \mathrm{~g}$ & Friable \\
\hline $0.2+0.0\left(\mathrm{~T}_{5}\right)$ & $0.00 \mathrm{j}$ & $0.00 \mathrm{f}$ & $0.00 \mathrm{~h}$ & - \\
\hline $0.2+0.5\left(\mathrm{~T}_{6}\right)$ & $59.58 \mathrm{~g}$ & $21.50 \mathrm{~b}$ & $0.42 \mathrm{~g}$ & Friable \\
\hline $0.2+2\left(\mathrm{~T}_{7}\right)$ & $76.67 \mathrm{c}$ & $20.67 \mathrm{c}$ & $1.47 \mathrm{a}$ & Compact \\
\hline $0.2+5\left(\mathrm{~T}_{8}\right)$ & $83.33 \mathrm{a}$ & $18.00 \mathrm{e}$ & $1.48 \mathrm{a}$ & Compact \\
\hline $0.5+0.0\left(\mathrm{~T}_{9}\right)$ & $0.00 \mathrm{j}$ & $0.00 \mathrm{f}$ & $0.00 \mathrm{~h}$ & - \\
\hline $0.5+0.5\left(\mathrm{~T}_{10}\right)$ & $69.58 \mathrm{f}$ & $21.58 \mathrm{~b}$ & $1.06 \mathrm{~d}$ & Friable \\
\hline $0.5+2\left(\mathrm{~T}_{11}\right)$ & $75.00 \mathrm{c}$ & 20.42 c & $0.57 \mathrm{f}$ & Friable \\
\hline $0.5+5\left(\mathrm{~T}_{12}\right)$ & $76.67 \mathrm{bc}$ & $20.17 \mathrm{c}$ & $0.73 \mathrm{e}$ & Friable \\
\hline $1.0+0.0\left(\mathrm{~T}_{13}\right)$ & $0.00 \mathrm{j}$ & $0.00 \mathrm{f}$ & $0.00 \mathrm{~h}$ & - \\
\hline $1.0+0.5\left(\mathrm{~T}_{14}\right)$ & $74.17 \mathrm{~d}$ & $18.50 \mathrm{de}$ & $1.35 \mathrm{~b}$ & Compact \\
\hline $1.0+2\left(\mathrm{~T}_{15}\right)$ & $78.75 \mathrm{~b}$ & $18.67 \mathrm{de}$ & $1.41 \mathrm{ab}$ & Compact \\
\hline $1.0+5\left(\mathrm{~T}_{16}\right)$ & $72.08 \mathrm{e}$ & $18.92 \mathrm{~d}$ & $1.20 \mathrm{c}$ & Compact \\
\hline
\end{tabular}

In a column, the figures followed by same letter(s) do not differ significantly

For root initiation the regenerated shoots were cultured on hormone free MS media and MS media with NAA $(0.1,0.2,0.3,0.4,0.5 \mathrm{mg} / \mathrm{L})$. There was no statistical difference for rooting among the explants. However, different concentrations of NAA showed highly significant variation in their effects on the rooting parameters under study. The rooting frequency reached up to $100.0 \%$ in MS medium without hormones and it required minimum number of days (6.63). The number of roots (6.88) per plant was also highest 
(Table 3) in this treatment. With the increase of NAA concentration, there was a gradual decrease in root induction frequency and number of roots per explant with an increase in the days required for root induction. A contradictory result was earlier reported by Wei et al. (2006); Sultana et al. (2004) and Lixin and HuaiMing (1998). They observed the highest frequency of root in medium supplemented with $0.1 \mathrm{mg} / \mathrm{L} \mathrm{NAA}$.

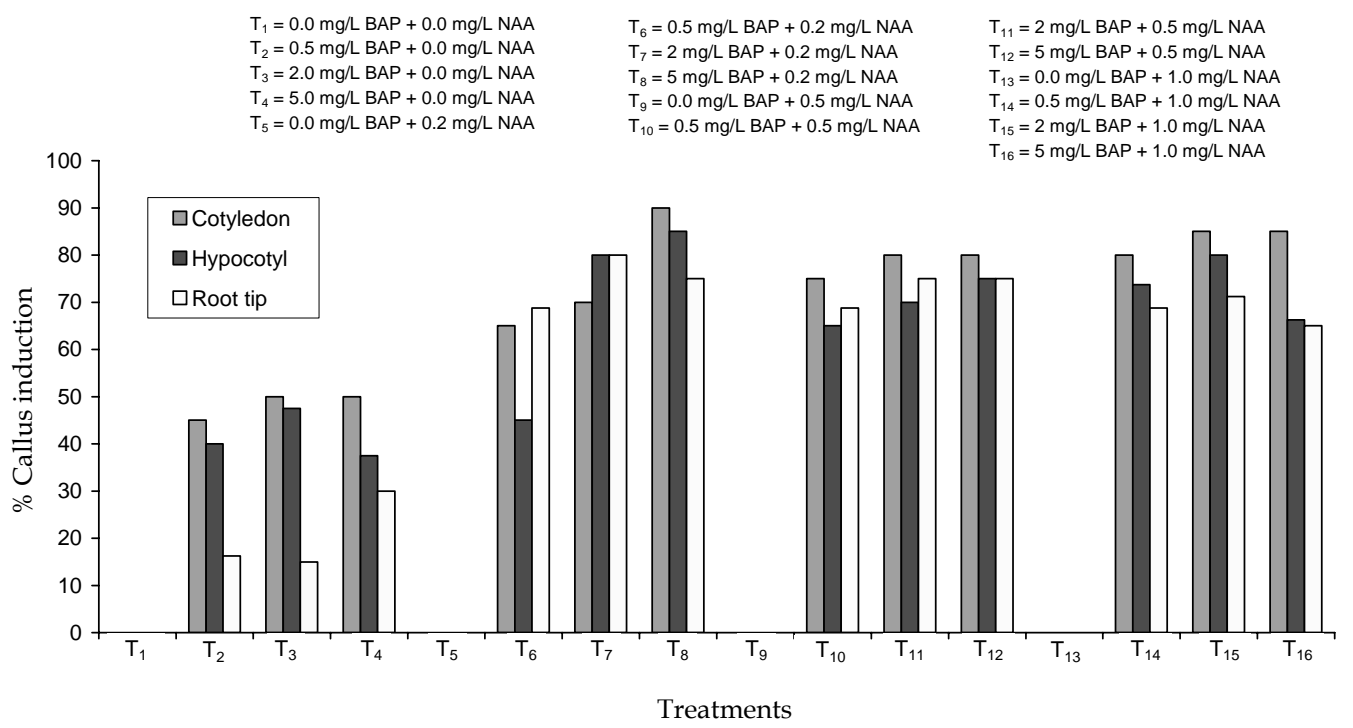

Fig. 1. Combined effect of explants and hormone concentrations on callus induction

Table 2. Combined effect of explants and hormone concentrations on shoot induction

\begin{tabular}{|c|c|c|c|c|c|}
\hline Explants & $\begin{array}{c}\text { Hormone concentration } \\
(\mathrm{mg} / \mathrm{L})\end{array}$ & $\begin{array}{l}\text { \% Shoot } \\
\text { induction }\end{array}$ & $\begin{array}{c}\text { Days required for } \\
\text { shoot induction }\end{array}$ & $\begin{array}{l}\text { No. of shoot } \\
\text { per explants }\end{array}$ & $\begin{array}{c}\begin{array}{c}\text { Shoot length } \\
(\mathrm{cm})\end{array} \\
\end{array}$ \\
\hline \multirow[t]{8}{*}{ Cotyledon } & Control $\left(\mathrm{T}_{1}\right)$ & $0.00 \mathrm{~h}$ & $0.00 \mathrm{c}$ & $0.00 \mathrm{~h}$ & $0.00 \mathrm{~d}$ \\
\hline & $1 \mathrm{BAP}\left(\mathrm{T}_{2}\right)$ & $0.00 \mathrm{~h}$ & $0.00 \mathrm{c}$ & $0.00 \mathrm{~h}$ & $0.00 \mathrm{~d}$ \\
\hline & $5 \mathrm{BAP}\left(\mathrm{T}_{3}\right)$ & $0.00 \mathrm{~h}$ & $0.00 \mathrm{c}$ & $0.00 \mathrm{~h}$ & $0.00 \mathrm{~d}$ \\
\hline & 1 Kinetin $\left(\mathrm{T}_{4}\right)$ & $0.00 \mathrm{~h}$ & $0.00 \mathrm{c}$ & $0.00 \mathrm{~h}$ & $0.00 \mathrm{~d}$ \\
\hline & 5 Kinetin $\left(\mathrm{T}_{5}\right)$ & $0.00 \mathrm{~h}$ & $0.00 \mathrm{c}$ & $0.00 \mathrm{~h}$ & $0.00 \mathrm{~d}$ \\
\hline & $1 \mathrm{BAP}+0.2 \mathrm{NAA}\left(\mathrm{T}_{6}\right)$ & $10.00 \mathrm{~g}$ & $42.25 \mathrm{a}$ & $1.75 \mathrm{~g}$ & $2.13 c$ \\
\hline & $2 \mathrm{BAP}+0.2 \mathrm{NAA}\left(\mathrm{T}_{7}\right)$ & $65.00 \mathrm{c}$ & $45.75 \mathrm{a}$ & $4.25 \mathrm{f}$ & $3.67 \mathrm{~b}$ \\
\hline & $5 \mathrm{BAP}+0.2 \mathrm{NAA}\left(\mathrm{T}_{8}\right)$ & $62.50 \mathrm{~cd}$ & $50.50 \mathrm{a}$ & $4.00 \mathrm{f}$ & $3.50 \mathrm{~b}$ \\
\hline \multirow[t]{8}{*}{ Shoot tip } & Control $\left(\mathrm{T}_{1}\right)$ & $57.50 \mathrm{de}$ & $10.50 \mathrm{bc}$ & $6.50 \mathrm{~d}$ & $3.70 \mathrm{~b}$ \\
\hline & $1 \mathrm{BAP}\left(\mathrm{T}_{2}\right)$ & $100.00 \mathrm{a}$ & $8.25 \mathrm{bc}$ & $13.25 \mathrm{a}$ & $4.43 \mathrm{a}$ \\
\hline & $5 \mathrm{BAP}\left(\mathrm{T}_{3}\right)$ & $55.00 \mathrm{e}$ & $11.75 \mathrm{bc}$ & $5.50 \mathrm{e}$ & $3.55 \mathrm{~b}$ \\
\hline & 1 Kinetin $\left(\mathrm{T}_{4}\right)$ & $65.00 \mathrm{c}$ & $11.50 \mathrm{bc}$ & $5.25 \mathrm{e}$ & $3.25 \mathrm{~b}$ \\
\hline & 5 Kinetin $\left(\mathrm{T}_{5}\right)$ & $47.50 \mathrm{f}$ & $14.75 \mathrm{~b}$ & 4.75 ef & $3.22 \mathrm{~b}$ \\
\hline & $1 \mathrm{BAP}+0.2 \mathrm{NAA}\left(\mathrm{T}_{6}\right)$ & $100.00 \mathrm{a}$ & $8.50 \mathrm{bc}$ & $13.50 \mathrm{a}$ & $4.45 \mathrm{a}$ \\
\hline & $2 \mathrm{BAP}+0.2 \mathrm{NAA}\left(\mathrm{T}_{7}\right)$ & $95.00 \mathrm{ab}$ & $11.75 \mathrm{bc}$ & $9.75 \mathrm{~b}$ & $3.85 \mathrm{~b}$ \\
\hline & $5 \mathrm{BAP}+0.2 \mathrm{NAA}\left(\mathrm{T}_{8}\right)$ & $92.50 \mathrm{~b}$ & $10.75 \mathrm{bc}$ & $8.50 \mathrm{c}$ & $3.60 \mathrm{~b}$ \\
\hline $\mathrm{LSD}_{(0.05)}$ & & 6.805 & 10.030 & 0.7813 & 0.5470 \\
\hline
\end{tabular}

In a column, the figures followed by the same letter(s) do not differ significantly 
Table 3. Main effect of hormone concentrations on root induction

\begin{tabular}{lcc|c}
\hline \multicolumn{1}{c|}{$\begin{array}{c}\text { Hormone concentration } \\
(\mathrm{mg} / \mathrm{L})\end{array}$} & \% root induction & $\begin{array}{c}\text { Days required for } \\
\text { root initiation }\end{array}$ & No. of roots/shoot \\
\hline MS without hormone $\left(\mathrm{T}_{1}\right)$ & $100.00 \mathrm{a}$ & $6.63 \mathrm{e}$ & $6.88 \mathrm{a}$ \\
$1 / 2 \mathrm{MS}\left(\mathrm{T}_{2}\right)$ & $90.00 \mathrm{ab}$ & $8.38 \mathrm{~d}$ & $3.88 \mathrm{~b}$ \\
$0.1 \mathrm{NAA}\left(\mathrm{T}_{3}\right)$ & $97.50 \mathrm{a}$ & $6.75 \mathrm{e}$ & $6.50 \mathrm{a}$ \\
$0.2 \mathrm{NAA}\left(\mathrm{T}_{4}\right)$ & $80.00 \mathrm{~b}$ & $10.50 \mathrm{c}$ & $3.25 \mathrm{c}$ \\
$0.3 \mathrm{NAA}\left(\mathrm{T}_{5}\right)$ & $67.50 \mathrm{c}$ & $12.25 \mathrm{~b}$ & $2.75 \mathrm{c}$ \\
$0.4 \mathrm{NAA}\left(\mathrm{T}_{6}\right)$ & $42.50 \mathrm{~d}$ & $14.38 \mathrm{a}$ & $1.75 \mathrm{~d}$ \\
$0.5 \mathrm{NAA}\left(\mathrm{T}_{7}\right)$ & $35.00 \mathrm{~d}$ & $14.38 \mathrm{a}$ & $1.50 \mathrm{~d}$ \\
\hline LSD $_{(0.05)}$ & 5.878 & 0.5823 & 0.5396 \\
\hline
\end{tabular}

In a column, the figures followed by the same letter(s) do not differ significantly

From the results obtained from the present research work as described above, it may be concluded that cotyledon explants are best for callus induction. However, shoot tip explants were better for in vitro regeneration than cotyledon explants. The direct regeneration was more rapid process than indirect regeneration via callus. Among the hormone combinations used, a combination of BAP at $5 \mathrm{mg} / \mathrm{L}$ and NAA at $0.2 \mathrm{mg} / \mathrm{L}$ was best for callus induction. On the other hand, $1 \mathrm{mg} / \mathrm{L} \mathrm{BAP}$ or $1 \mathrm{mg} / \mathrm{L}$ BAP in addition to $0.2 \mathrm{mg} / \mathrm{L}$ NAA was best for shoot induction and hormone free MS media was found best for rooting of in vitro regenerated shoots of sweet gourd (Fig. 1C).

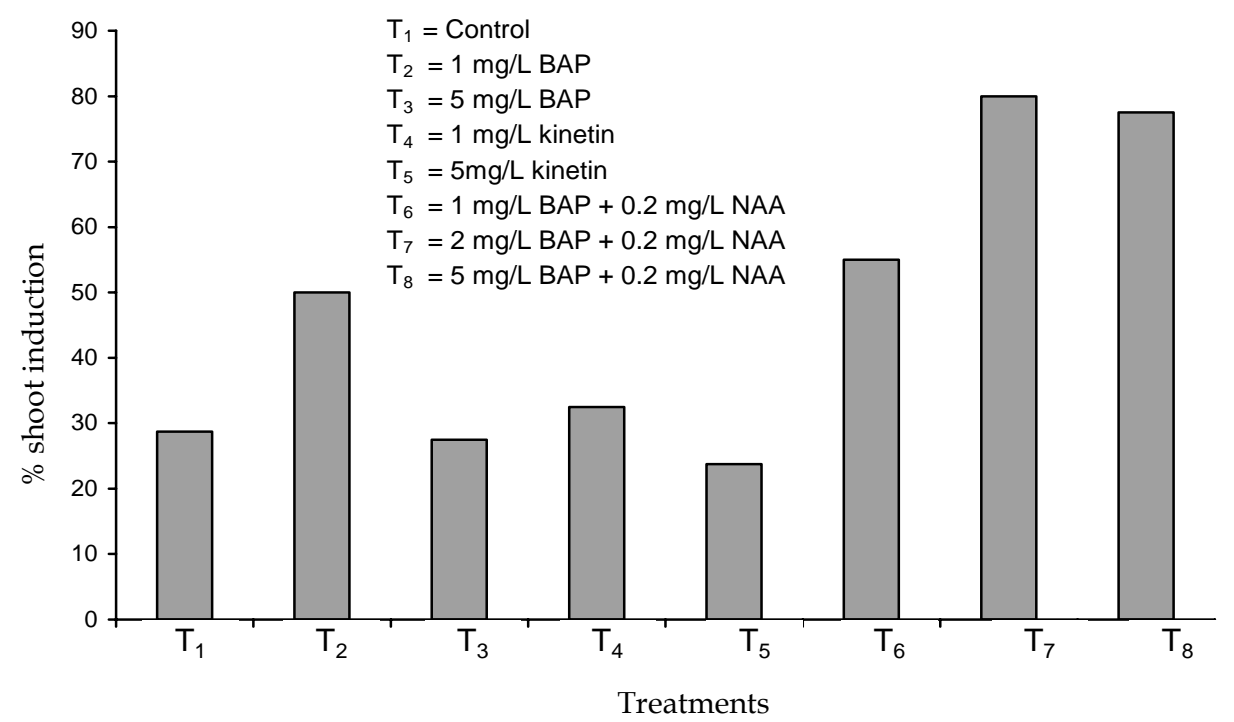

Fig. 2. Main effect of hormone concentrations on $\%$ shoot induction

In conclusion, the callus formation and regeneration ability of the explants have the potential for future biotechnological studies for the improvement of sweet gourd. Here a 
direct in vitro regeneration protocol was developed. However, further study is needed with different explants to standardize the protocol of regeneration via callus.
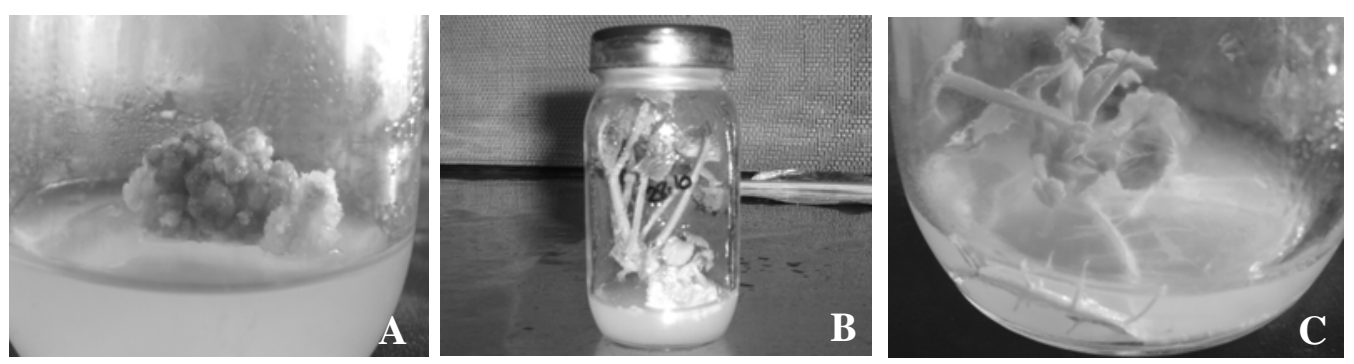

Fig. 1. A) Callus proliferation from cotyledon explants in $5 \mathrm{mg} / \mathrm{L} \mathrm{BAP}+1.0 \mathrm{mg} / \mathrm{L} \mathrm{NAA}$ at 42 days after inoculation. B) Direct shoot regeneration from shoot tip explants on $1 \mathrm{mg} / \mathrm{L}$ BAP at 45 days after inoculation. C) Root formation from regenerated shoot in hormone free MS medium at 80 days after inoculation.

\section{REFERENCES}

Awal, A. S. M., Alam, M. J., Ali, M. R. and Hasan, M. N. 2005. In vitro propagation of pointed gourd (Trichosanthes dioica Roxb.) from shoot tips. Biotechnol., 4(3) : 221-224.

Hegazi, H. H. 1999. Genotypic differences in callus formation and shoot forming capacity of some vegetable species. Arab Univ. J. Agric. Sci., 7(2) : 507-520.

Murashige, T. and Skoog F. 1962. A revised medium for rapid growth and bioassays with tobacco tissue cultures. Physiol. Plant., $15: 473-497$.

Robinson, R. W. and Walters, D. S. D. 1997. Cucurbits. CAB International, Wallingford, UK. 226 p.

Selvaraj, N., Vasudevan A., Manickavasagam M., Kasthurirengan S. and Ganapathi A. 2007. High frequency shoot regeneration from cotyledon explants of cucumber via organogenesis. Scientia Hortic., 112(1) : 2-8.

Urbanek, A., Zechmann, B. and Müller, M. 2005. Plant regeneration via somatic embryogenesis in Styrian pumpkin: cytological and biochemical investigations. Plant Cell Tiss. Org. Cult., 79(3) : 329-340.

Vasudevan, A., Selvaraj N., Sureshkumar, P. and Ganapathi, A. 2001. Multiple shoot induction from the shoot tip explants of cucumber (Cucumis sativus L.). Cucurbit Genet. Cooperative, $24: 8-12$.

Whitaker, T. W. and Davis G. N. 1962. Cucurbits. Inter Science Publishers, INC., New York. pp. 13-136.

Zhao, J. 1999. In vitro culture of cotyledon explants of Cucurbita moschata. Acta Hortic. Sinica, 26(3) : 196-197.

Wei, L., Jian C., MaoYing, M. Z. and Wei, W. 2006. Tissue culture and rapid propagation of Trichosanthes kirilowii Maxim. J. Plant Res. Environ., 15(4) : 73-74.

Sultana, R. S., Bari. M. A., Rahman, M. H., Rahman, M. M., Siddique, N. A. and Khatun, N. 2004. In vitro rapid regeneration of plantlets from leaf explant of watermelon (Citrullus lanatus Thumb.). Biotechnol., 3(2) : 131-135.

LiXin, H. and HuaiMing, W. 1998. A study on building up the regeneration system of watermelon. Acta Agric. Boreali Sinica, 13(3) : 112-115. 